(C) 2016

Кулик М. І., кандидат сільськогосподарських наук

Полтавська державна аграрна академія

\title{
УРОЖАЙНІСТЬ СОРТІВ ПРОСА ПРУТОПОДІБНОГО П'ЯТОГО РОКУ ВЕГЕТАЦЇ̈ ЗАЛЕЖНО ВІД БІОМЕТРИЧНИХ ПОКАЗНИКІВ РОСЛИН
}

\section{Рецензент - доктор сільськогосподарських наук, професор Г. П. Жемела}

Досліджено варіабельність біометричних (кількісних) показників рослин проса прутоподібного за досліджуваними сортами різних груп стиглості. Наведено рівень урожайності вегетативної надземної маси культури та встановлено кореляційні залежності між кількісними показниками рослин п'ятого року вететації та урожайністю сухої фітомаси. Визначено, шуо урожайність сухої вететативної надземної маси досліджуваних сортів проса прутоподібного обумовлюеться вмістом сухої речовини у фітомасі, кількістю стебел на одиницю площі, довжиною прапориевого листка та вмістом вологи у рослинах.

Ключові слова: світчграс, біометричні показники, урожайність, кореляиія, фітомаса.

Постановка проблеми. На даний час, в умовах дефіциту енергоресурсів у світі все більше уваги приділяється можливості використання альтернативних джерел енергії, в т.ч. спеціально вирощених енергетичних культур і доступного потенціалу рослинних решток сільськогосподарського господарства. Водночас наша країна має великий потенціал біомаси, доступної для енергетичного використання, має добрі передумови для розширення використання рослинних решток на біопаливо. Енергетична стратегія України до 2030 року [1] передбачає динамічне зростання обсягів використання енергії біомаси в 2015 р. до 5 млн тонн умовного палива (т у. п.), або це 2,5\% від загального енергоспоживання, а в 2030 році до 20 млн т у. п. або до $10 \%$.

Доцільність використання енергії біомаси обгрунтовує М. Руденко і стверджує, що енергія, як абсолютна додаткова вартість, є важливим критерієм екологічної збалансованості економіки країни, оскільки відповідає принципові збереження природної впорядкованості, що надходить 3 енергією Сонця на Землю і трансформується в енергетичний потенціал рослин [14]. Тому виникає потреба в освоєнні енергії відновлюваних джерел, насамперед, накопичуваної рослинами, тобто біоенергіï.

Все це засвідчує актуальність проведення відповідних досліджень із вивчення потенціалу доступного рослинного енергетичного ресурсу за вирощування високоврожайних енергетичних культур в умовах нашої країни, можливості використання їхньої вегетативної надземної маси для отримання енергоємного біопалива та часткового зміщення непоновлюваних джерел енергії.

Аналіз основних досліджень і публікацій, у яких започатковано розв'язання проблеми. Як зазначає В. Л. Курило зі співавторами [7], Україна за природно-економічними чинниками належить до країн із надзвичайно сприятливими умовами для забезпечення продовольчої безпеки та має високий потенціал створення стабільного ринку енергетичних культур для використання в біопаливній промисловості. Залучення відновлюваних джерел енергії усіх видів і, передусім, біомаси шляхом трансформації енергії фотосинтезу в доступній для використання в економіці держави формі сприятиме зниженню рівня енергозалежності України.

На даний час значну кількість рослин на території нашої країни вже досліджено для визначення можливості використання їхнього енергетичного потенціалу, але лише невелику кількість культур вирощують на значних площах. Серед них найбільш поширеними є представники родів Miscanthus (види міскантуса), Salix (верба), Populus (тополя) та Panicum (просо прутоподібне - світчграс). Ці рослини культивують на одному місці декілька років, а технологія вирощування не потребує значних матеріальних та енергетичних затрат [13].

3-поміж вищеперелічених енергетичних культур світчграс є однією з рослин, у якої низька собівартість виробництва фітомаси - сировини для виробництва біопалива та висока продуктивність надземної вегетативної маси за багаторічного циклу використання.

У зв'язку з високою урожайністю проса прутоподібного та широкого географічного поширення, можливості його вирощування на грунтах різної якості, незначних вимог рослин до вмісту вологи та поживних речовин у грунті і позитивного впливу на навколишнє середовище Департамент енергетичних ресурсів США обрав світчграс як модель лігноцелюлозної культури для 
вирощування біомаси з метою виробництва енерriï [16].

За вивчення інтродукції проса прутоподібного в нашій країні визначено, що ця культура є високопродуктивною, яка під час акліматизації в умовах центральної частини України на малопродуктивних грунтах забезпечує потужний стеблостій на другий-третій рік вегетації, формує стабільну врожайність фітомаси (сировини для виробництва біопалива) та насіннєву продуктивність $[5,11]$.

Д. Б. Рахметов, О. М. Вергун та С. О. Рахметова встановили [12], що рослини Panicum virgatum за роки дослідження характеризувалися високими ростовими параметрами, урожаєм та цінним хімічним складом. Основні морфометричні параметри рослин проса прутоподібного залежали від умов вегетації, періоду розвитку та формових особливостей.

Дослідження, проведені автором, в умовах центральної частини Лісостепу на збіднених на поживні речовини грунтах $[4,6]$ свідчать, що найбільш продуктивними за кількісними показниками (висотою рослин та їхньою густотою, а також вмістом сухої речовини у фітомасі), 3 рівнем врожайності виявилися сорти світчграсу Кейв-ін-рок і Картадж, менш урожайним був сорт Форесбург.

Отже, недостатньо вивчені особливості формування урожайності сортів проса прутоподібного залежно від біометричних показників рослин за багаторічного циклу вирощування в умовах України викликають необхідність більш детально дослідити це питання.

Мета досліджень полягає у встановленні впливу біометричних (кількісних) показників рослин на урожайність надземної вегетативної фітомаси сортів проса прутоподібного п'ятого року вегетації.

Відповідно до поставленої мети досліджень передбачалось вирішення наступних завдань:

1. Визначити біометричні показники рослинного фітоценозу сортів проса прутоподібного.

2. Встановити урожайність сортів проса прутоподібного за сухою вегетативною масою.

3. Провести кореляційно-регресійний аналіз кількісних показників рослин, їхньої продуктивності (волога та суха маса рослин) та урожайністю сухої фітомаси сортів проса прутоподібного.

Методика проведення досліджень. Експериментальна робота виконана згідно 3 міжнародною науковою тематикою «Pellets for Power» (2011-2013 рр.) та державною науководослідною темою «Агроекологічні засади виро- щування енергетичних культур в умовах України» (2014-2017 pp.).

Дослід був закладений у центральній частині Лісостепу на деградованих грунтах, що мали наступні агрохімічні характеристики: вміст гумусу - 2,07 \%; азоту - 44,8; фосфору - 65,0 і калію 113,0 мг на 1 кг грунту.

Протягом 2011-2015 років на вивчення були поставлені наступні сорти світчграсу: ранньостиглі - Дакота і Небраска, середньостиглі Кейв-ін-рок, Форесбург і Санбурст, та пізньостиглі - Картадж, Шелтер, Аламо, Канлоу. В даному повідомленні подано результати 2015 року.

Під час проведення багаторічних досліджень застосовували як загальноприйняті методики [3, 10], так і спеціальні $[8,9]$. Урожайність фітомаси світчграсу визначали шляхом скошування снопових зразків, їхнього зважування, висушування відібраної проби та перерахунку на суху масу 3 урахуванням вологості сировини [15].

Для побудови кореляційної плеяди визначали кореляційно-регресійну залежність між урожайністю сухої фітомаси, т/га (У) і біометричними показниками рослин проса прутоподібного: ВР висота рослин (см); КС - кількість стебел (шт./м.П.); КЛ - кількість листків на рослині (шт.); ДПЛ - довжина прапорцевого листка (см); ЗКЛ - загальна кількість листків (шт./м.п.); $\mathrm{B}_{\mathrm{cp}}-$ вміст сухої речовини у фітомасі (т/га); $\Pi_{c \phi}-$ продуктивність сухої фітомаси (кг/м.П.); $\Pi_{в ф}-$ продуктивність вологої фітомаси (кг/м.п.); ВВ вміст вологи у фітомасі (\%).

Отримані результати досліджень, що апробовані в досліді, обробляли за сучасними методами статистики iз застосуванням ліцензійних комп'ютерних програм Excel та Statistica 6.0 та відповідних методик [2].

Результати досліджень. Залежно від сортових особливостей, біометричні показники рослин проса прутоподібного характеризувалися значним варіюванням біометричних показників (табл. 1).

В умовах 2015 року, на п'ятий рік вегетації, середня висота рослин досліджуваних сортів проса прутоподібного змінювалась у межах від 142,3 до 192,4 см, кількість стебел на м.П. - від 317,2 до 495,4 шт., кількість листків на рослині від 4,4 до 5,9 шт., довжина прапорцевого листка - від 34,7 до 45,2 см, а загальна кількість листків на м.п. була від 1496,9 до 2904,0 штук.

Варіювання кількісних показників у середньостиглих сортів світчграсу за висотою і густотою рослин було від 146,9 см і 345,1 шт. (Кейв-інрок) до 155,0 см і 356,5 шт. (Самбурст). 
1. Біометричні показники рослин проса прутоподібного п'ятого року вететації, 2015 р.

\begin{tabular}{|c|c|c|c|c|c|}
\hline \multirow{2}{*}{ Сорт } & \multirow{2}{*}{$\begin{array}{c}\text { Висота } \\
\text { рослин, см }\end{array}$} & $\begin{array}{c}|c| \\
\text { стебел, } \\
\text { шт./м.П. }\end{array}$ & $\begin{array}{c}\text { листків, } \\
\text { шт./рослину }\end{array}$ & $\begin{array}{c}\text { Довжинтків, } \\
\text { шт./м.п. }\end{array}$ & $\begin{array}{c}\text { прапорцевого } \\
\text { листка, см }\end{array}$ \\
\cline { 5 - 6 } & 142,3 & 317,2 & 4,4 & 1395,7 & 34,7 \\
\hline Дакота & 138,5 & 321,6 & 4,6 & 1479,4 & 35,9 \\
\hline Небраска & 146,9 & 345,1 & 5,3 & 1829,0 & 41,6 \\
\hline Кейв-ін-рок & 144,4 & 355,1 & 4,9 & 1740,0 & 36,3 \\
\hline Форесбург & 155,0 & 356,5 & 5,0 & 1782,5 & 36,9 \\
\hline Самбурст & 192,4 & 395,4 & 5,5 & 2174,7 & 45,2 \\
\hline Картадж & 190,2 & 379,3 & 5,7 & 2162,0 & 44,8 \\
\hline Шелтер & 185,4 & 363,2 & 5,1 & 1852,3 & 42,9 \\
\hline Аламо & 191,7 & 392,1 & 5,9 & 2313,4 & 43,4 \\
\hline Канлоу & 4,3 & 21,7 & 0,17 & 243,1 & 0,34 \\
\hline НІР & & &
\end{tabular}

Для пізніх сортів зафіксовано найбільшу висоту рослин у сорту Картадж (192,4 см), Шелтер (190,2 см) і Канлоу (191,7 см) за кількості стебел, відповідно за сортами - 395,4; 379,3 і 392,1 шт./м.П., суттєво меншими ці показники були у сорту Аламо. 3-поміж сортів проса прутоподібного, поставлених на вивчення, у ранньостиглої групи висота рослин і кількість стебел на м.п. була відповідно за показниками 142,3 см і 317,2 шт. (Дакота) і 138,5 см і 321,6 шт. (Небраска).

Найбільші значення кількісних показників рослин (висоти і густоти стеблостою, облиствленості рослин та довжини прапорцевого листка) були отримані у сортів світчграсу пізньої групи стиглості (Картадж, Аламо і Канлоу), найменші - у ранньостиглих сортів (Дакота і Небраска), проміжне значення мали середньостиглі сорти Кейв-ін-рок, Форесбург і Санберст.
Урожайність фітомаси проса прутоподібного залежить як від продуктивності кожної рослини у фітоценозі, так і від умісту вологи в ній на час збирання врожаю (табл. 2).

За результатами досліджень було встановлено, що вага сухого снопа, як і середня маса однієї рослини світчграсу, залежали від вмісту вологи у фітомасі, що в умовах 2015 року змінювався за сортами від 24,5 до $31,7 \%$, і обумовлювалася сортовими особливостями культури.

Під час вирощування проса прутоподібного в умовах п'ятого року вегетації найбільша урожайність сухої фітомаси зафіксована у сортів Картадж, Канлоу та Шелтер, відповідно - 13,3; 13,0 і 12,5 т/га, меншим цей показник був у сортів Кейв-ін-рок, Самбурст і Форесбург - 11,5; 11,8 і 10,7 т/га і суттєво найменшим - у сортів Небраска (9,7 т/га) і Дакота (6,9 т/га).

\section{2. Продуктивність рослин (волога та суха маса), вміст вологи і урожайність} фітомаси проса прутоподібного п'ятого року вететації, 2015 р.

\begin{tabular}{|l|c|c|c|c|c|c|c|}
\hline \multirow{2}{*}{ Сорт } & Вага воло- & Вміст & Вага сухо- & \multicolumn{2}{|c|}{ Вага рослини, г } & \multicolumn{2}{|c|}{ Урожайність, т/га } \\
\cline { 7 - 9 } & кг & $\begin{array}{c}\text { вологи, } \\
\text { го сноп, } \\
\text { кг }\end{array}$ & $\begin{array}{c}\text { до висушу- } \\
\text { вання }\end{array}$ & $\begin{array}{c}\text { після вису- } \\
\text { шування }\end{array}$ & $\begin{array}{c}\text { вологої } \\
\text { маси }\end{array}$ & сухої маси \\
\hline Дакота & 2,771 & 24,9 & 0,690 & 8,7 & 2,2 & 27,7 & 6,9 \\
\hline Небраска & 3,959 & 24,5 & 0,970 & 12,3 & 3,0 & 39,6 & 9,7 \\
\hline Кейв-ін-рок & 4,356 & 26,4 & 1,150 & 12,6 & 3,3 & 43,6 & 11,5 \\
\hline Форесбург & 4,147 & 25,8 & 1,070 & 11,7 & 3,0 & 41,5 & 10,7 \\
\hline Самбурст & 4,504 & 26,2 & 1,180 & 12,6 & 3,3 & 45,0 & 11,8 \\
\hline Картадж & 4,700 & 28,3 & 1,330 & 11,9 & 3,4 & 47,0 & 13,3 \\
\hline Шелтер & 4,102 & 31,7 & 1,210 & 10,8 & 3,2 & 41,0 & 12,1 \\
\hline Аламо & 3,754 & 29,5 & 1,190 & 10,3 & 3,3 & 37,5 & 11,9 \\
\hline Канлоу & 4,167 & 31,2 & 1,300 & 10,6 & 3,3 & 41,7 & 13,0 \\
\hline
\end{tabular}


СІЛЬСЬКЕ ГОСПОДАРСТВО. РОСЛИННИЦТВО

3. Кореляційні зв'язки кількісних показників рослин і врожайності сухої рітомаси проса прутоподібного n'ятого року вететацї, 2015 p.

\begin{tabular}{|c|c|c|c|c|c|c|c|}
\hline Показники & ВР & \multirow{2}{*}{ КС } & КЛР & ЗКЛ & ДПЛ & \multirow{2}{*}{ ВВ } & у \\
\hline ВР & - & 0,97 & 0,76 & 0,96 & 0,79 & 0,88 & 0,54 \\
\hline КС & 0,97 & - & 0,43 & 0,39 & 0,88 & 0,91 & 0,80 \\
\hline КЛР & 0,76 & 0,43 & - & 0,89 & 0,78 & 0,87 & 0,46 \\
\hline ЗКЛ & 0,96 & 0,39 & 0,89 & - & 0,88 & 0,94 & 0,55 \\
\hline ДПЛ & 0,79 & 0,88 & 0,78 & 0,88 & - & 0,80 & 0,76 \\
\hline ВВ & 0,88 & 0,91 & 0,87 & 0,94 & 0,80 & - & $-0,73$ \\
\hline У & 0,54 & 0,80 & 0,46 & 0,55 & 0,76 & $-0,73$ & - \\
\hline
\end{tabular}

Примітка: коефіцієнти кореляції достовірні за 5 \% рівні значущості

За проведення кореляції встановлені зв'язки між кількісними показниками рослин проса прутоподібного та урожайністю сухої фітомаси (табл. 3).

За детермінацією ознак (d) можна стверджувати про відсотковий вплив біометричних показників на урожайність культури. Так, кількісні показники рослин: густота стеблостою $(\mathrm{d}=$ $64 \%)$ та довжина прапорцевого листка $(\mathrm{d}=$
58 \%) мають сильні кореляційні зв'язки (r>0,7) 3 продуктивністю культури і обумовлюють урожайність сортів проса прутоподібного п'ятого року вегетації. Водночас урожайність сухої фітомаси досліджуваних сортів світчграсу має обернений зв'язок із вмістом вологи у ній, що свідчить про те, що зі зниженням одного показника буде зростати значення іншого та навпаки; детермінація становить $53 \%$.

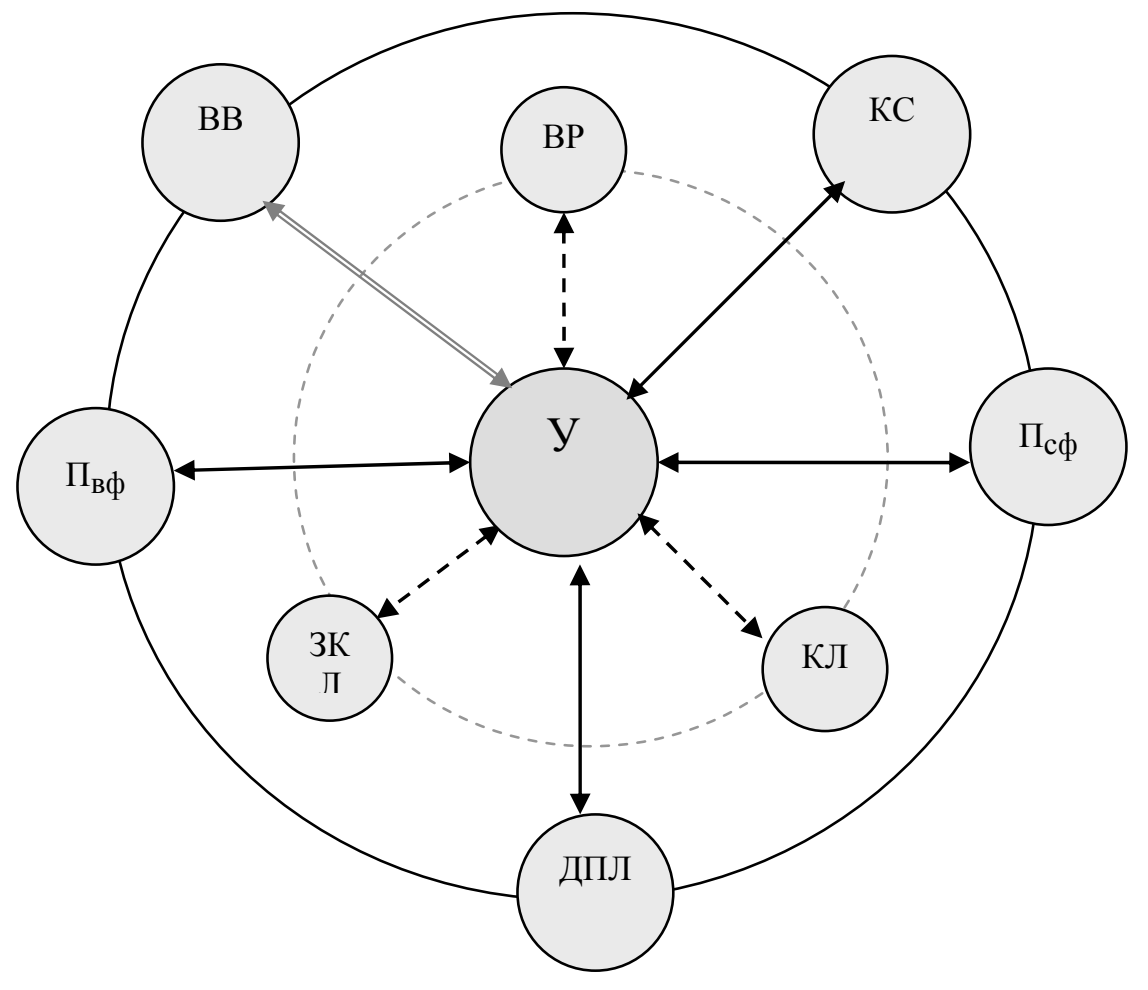

Примітка:

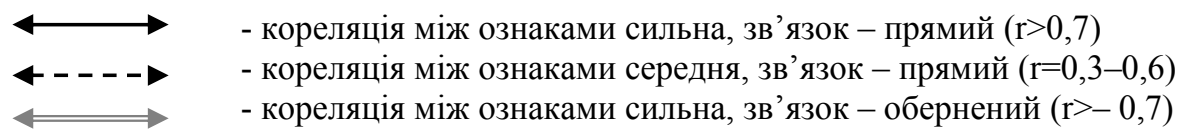

Рис. Кореляційна плеяда залежності між кількісними показниками рослин і врожайністю сухої фітомаси проса прутоподібного п'ятого року вегетації, 2015 р. 


\section{СІЛЬСЬКЕ ГОСПОДАРСТВО. РОСЛИННИЦТВО}

Відповідно до проведених статистичних розрахунків і одержаних результатів кореляційнорегресійного аналізу була побудована комплексна кореляційна плеяда 3 тих кількісних показників рослин, що мають істотний вплив на формування урожайності сухої фітомаси досліджуваних сортів проса прутоподібного (див. рис.).

Урожайність надземної сухої вегетативної маси проса прутоподібного залежить від кількості стебел на одиницю площі, продуктивності сухої i вологої фітомаси та довжини прапорцевого листка (отримали прямолінійний зв'язок, коефіцієнти кореляції більше 0,7$)$; обернений - із вмістом вологи у фітомасі. Середній прямолінійний кореляційний зв'язок виявлено між урожайністю сухої фітомаси та кількістю листків на рослині, висотою стеблостою і загальною кількістю листків у ньому.

\section{Висновки:}

1. Рослини проса прутоподібного п'ятого вегетаційного року формують найвищі значення кіль-

\section{БІБЛІОГРАФІЯ}

1. Енергетична стратегія України на період до 2030 року // Інформаційно-аналітичний бюлетень «Відомості Міністерства палива та енергетики України» : Спеціальний випуск. - 2006. $113 \mathrm{c}$.

2. Боровиков В. П. Statistica. Искусство анализа данных на компьютере: для профессионалов / В. П. Боровиков. - СПб. : Питер, 2003. - 688 с.

3. Доспехов Б. А. Методика полевого опыта / Б. А. Доспехов. - М. : Колос, 1985. - 336 с.

4. Кулик М. I. Вплив елементів технології вирощування на урожайність сортів проса прутоподібного / М. І. Кулик // Екологічні, соціальні й економічні аспекти розвитку АПК на засадах раціонального природокористування : колективна монографія ; за ред. П. В. Писаренка, Т. О. Чайки, О. О. Ласло. - Полтава : Сімон, 2015. С. 194-205.

5. Кулик М. I. Формування продуктивності інтродукованого в центральній частині України Panicum virgatum L. (Проса лозоподібного) / М. І. Кулик, С. О. Юрченко : зб. наук. праць «Фактори експериментальної еволюції організмів». - К. : Укр. т-во генетиків і селекціонерів ім. М. І. Вавилова, 2014. - Т.14. - С. 160-164.

6. Кулик М. I. Мінливість кількісних показників проса прутоподібного (Panicum virgatum L.) залежно від сорту / M. I. Кулик : матеріали Міжнар. наук.-практ. конф., присвяченої пам'яті професора М. М. Чекаліна [«Генофонд рослин та його використання в сучасній селекції»], 22-23 квітня 2015 р. - Полтава : видавець Р. В. Шевченко, кісних (біометричних) показників наступних сортів: пізньостиглі сорти - Картадж, Шелтер і Канлоу; на високому рівні ці показники були у середньостиглих сортів світчграсу - Кейв-ін-рок і Самбурст, суттєво меншими - у ранньостиглих сортів (Небраска і Дакота).

2. 3-поміж досліджуваних сортів найбільшу врожайність сухої фітомаси для умов п'ятого року вегетації встановлено у пізньостиглих сортів проса прутоподібного - Картадж (13,3 т/га), Канлоу (13,0 т/га) і Шелтер (12,1 т/га) та середньостиглих - Кейв-ін-рок (11,5 т/га) і Самбурст (11,8 т/га).

3. Згідно з кореляційно-регресійним аналізом визначено, що урожайність сухої вегетативної надземної маси досліджуваних сортів проса прутоподібного обумовлюється вмістом сухої речовини у фітомасі, кількістю стебел, довжиною прапорцевого листка та вмістом вологи у рослинах.

2015. - C. 89-90.

7. Курило В. Л. Біоенергетика в Україні: стан та перспективи розвитку / В. Л. Курило, М. В. Роїк, О. М. Ганженко // Біоенергетика. - 2013. - №1. C. 5-10.

8. Методичні рекомендації з проведення основного та передпосівного обробітку грунту і сівби проса лозовидного / [Курило В. Л., Гументик М. Я., Гончарук Г. С. та ін.]. - К. : Інститут біоенергетичних культур і цукрових буряків НААН, 2012. $26 \mathrm{c}$.

9. Методичні рекомендації по технології вирощування енергетичних культур (світчграсу) в умовах України / [Писаренко П. В., Кулик М. І., Elbersen W. Н. та ін.]. - Полтава : Полтавська ДАА, 2011. -40 c.

10. Мойсейченко В. Ф. Основы научных исследований в агрономии / [В. Ф. Мойсейченко, М. Ф. Трифонова, А. Х. Заверюха и др.]. - М. : Колос, 1996. - 336 с.

11. Світчграс як нова фітоенергетична культура / [Мороз О. В., Смірних В. М., Курило В. Л. та iн.] // Цукрові буряки. - Київ, 2011. - Вип. №3 (81). - C. 12-14.

12. Рахметов Д. Б. Panicum virgatum L. - перспективний інтродуцент у Національному ботанічному саду ім. М. М. Гришка НААН України / Д. Б. Рахметов, О. М. Вергун, С. О. Рахметова // Інтродукція рослин. - Вип. 3(63), 2014. - С. 4-12.

13. Ефективність вирощування високопродуктивних енергетичних культур / [Роїк М. В., Курило В. Л., Гументик М. Я. та ін.] // Вісник 
Львівського національного аграрного університету. - 2011. - №15 (2). - С. 85-90.

14. Руденко М. Д. Энергия прогресса / Микола Данилович Руденко : пер. с укр. - К. : А. А. Михайлюта, 2010. - 544 c.

15. Kulyk M. Methods of calculation productivity phytomass for switchgrass in Ukraine / M. Kulyk, W. Elbersen. - Poltava, 2012. - 10 p.
16. McLaughlin S. B. Evaluating physical, chemical, and energetic properties of perennial grasses as biofuels / S. B. McLaughlin, R. Samson, D. Bransby at all // Bioenergy '96 : Proceedings of the Seventh National Bioenergy Conference. Sept. 15-20, 1996. Nashville, Tennessee. - V. 1. - P. 1-8. 